\title{
Correction to: Moving Beyond Lewis: Employment and Wage Trends in China's High- and Low-Skilled Industries and the Emergence of an Era of Polarization
}

\author{
Scott Rozelle ${ }^{3}$ Yiran Xia ${ }^{2}$ - Dimitris Friesen ${ }^{3}$ - Bronson Vanderjack ${ }^{1}$. \\ Nourya Cohen ${ }^{1}$
}

Published online: 19 November 2020

(c) The Author(s) 2020

\section{Correction to: Comparative Economic Studies https://doi.org/10.1057/s41294-020-00137-w}

Due to an unfortunate oversight, the corresponding author of this article has been interchanged. It should be Yiran Xia.

Open Access This article is licensed under a Creative Commons Attribution 4.0 International License, which permits use, sharing, adaptation, distribution and reproduction in any medium or format, as long as you give appropriate credit to the original author(s) and the source, provide a link to the Creative Commons licence, and indicate if changes were made. The images or other third party material in this article are included in the article's Creative Commons licence, unless indicated otherwise in a credit line to the material. If material is not included in the article's Creative Commons licence and your intended use is not permitted by statutory regulation or exceeds the permitted use, you will need to obtain permission

The original article can be found online at https://doi.org/10.1057/s41294-020-00137-w.

Yiran Xia

xiayiran@wzu.edu.cn

Scott Rozelle

rozelle@stanford.edu

Dimitris Friesen

dfriesen@stanford.edu

Bronson Vanderjack

bpvander@stanford.edu

Nourya Cohen

nacohen@stanford.edu

1 Stanford University, Stanford, USA

2 School of Business, Wenzhou University, Wenzhou, China

3 Rural Education Action Program, Freeman Spogli Institute, Stanford University, Stanford, USA 
directly from the copyright holder. To view a copy of this licence, visit http://creativecommons.org/licen ses/by/4.0/.

The original article has been corrected.

Publisher's Note Springer Nature remains neutral with regard to jurisdictional claims in published maps and institutional affiliations. 